\title{
Occupational Exogenous Lipoid Pneumonia: A Commonly Delayed Diagnosis
}

\author{
Mesleksel Eksojen Lipoid Pnömoni: Genellikle Gecikmiş Tanı \\ Feriel Dhouib, Mounira Haijaii, Kaouthar Jmal Hammami, Mohamed Larbi Masmoudi
}

\begin{abstract}
Exogenous lipoid pneumonia is an uncommon disease and an occupational etiology is rare. Occupational cases are usually related to aspiration of lipid substances, such as in cases of those who siphon fuel and fire-eaters. Presented here is a rare case of exogenous lipoid pneumonia in a mechanic using a grease spray for lubrication in whom diagnosis was delayed for 2 years because physicians initially neglected to consider his occupational history. Avoidance of occupational exposure to the causal agent was the main treatment and subsequent monitoring confirmed clinical and radiological improvement.
\end{abstract}

Key words: Lipoid pneumonia, occupational exposure, lubricant.

\section{Özet}

Exogenous lipoid pnömoni seyrek görülen bir hastalıktır ve mesleksel etyoloji de nadirdir. Mesleki maruziyete bağlı olgular, genellikle sifonerler ve ateş yutanlar gibi lipid maddelerin aspirasyonundan kaynaklanırlar. Biz, makinaları onaran ve yağlama için yağ spreyi kullanan bir hastada, eksojen lipoid pnömoni olgusunu sunuyoruz. Hastanın mesleki maruziyetlerinin ihmal edilmesi nedeniyle tanısı iki yıl gecikmişti. Ana tedavi, nedensel ajana maruz kalmanın önlenmesidir. İzlemlerinde klinik ve radyolojik iyileşme görüldü.

Anahtar Sözcükler: Lipoid pnömoni, mesleki maruziyet, yağlayıcı madde.
Exogenous lipoid pneumonia (ELP) is an uncommon disease, resulting from the inhalation or aspiration of fatty substances. ELP related to occupational exposure to oily substances is even rarer. A French study indicated that the majority of cases were not related to occupational exposure (1). The clinical presentation of this disease is not specific and often leads to confusion with bacterial pneumonia and pulmonary tuberculosis (2). As a result, diagnosis can be delayed and symptoms can persist for a long period. The objective of this report was to present a case of ELP due to occupational exposure to a grease spray, and to emphasize the importance of occupational history, which can lead to the etiological diagnosis.

Department of Occupational Medicine, Hospital Hedi Chaker, Sfax, Tunisia

Submitted (Başvuru tarihi): 28.03.2018 Accepted (Kabul tarihi): 02.10.2018

Correspondence (iletişim): Feriel Dhouib, Department of Occupational Medicine, Hospital Hedi Chaker, Sfax, Tunisia

e-mail: feriel.dhouib@gmail.com 


\section{CASE}

A 38-year-old male with a 10 pack-year smoking history, presented at the hospital with dyspnea, a cough, and a fever. He also reported unquantified weight loss and anorexia. He had been employed as an engine mechanic with a service company in the petroleum products sector for the past 8 years. The physical examination was normal. There were no laboratory abnormalities. A chest $X$ ray revealed a diffuse reticulonodular pattern throughout both lungs (Figure 1).

The patient had previously received empirical antibiotic treatment for bacterial pneumonia. Due to the lack of any regression of symptoms, pulmonary tuberculosis was suspected; however, a sputum smear and culture were negative. A thorax computed tomography scan revealed diffuse micronodules and bilateral airspace consolidations (Figures 2 and 3).

The patient was suspected to have a systemic autoimmune disease, but there was no detectable circulating antibody. Bronchoscopy was performed and revealed no macroscopic lesion. The bronchoalveolar lavage (BAL) fluid revealed an increased proportion of macrophages (92\%). Multiple biopsy sampling demonstrated histological features of bronchiolitis obliterans organizing pneumonia. The patient then underwent systemic corticotherapy and there was still little improvement in symptoms. Two years later, the patient was referred to an occupational medicine department to investigate an occupational origin to the pneumonia. The patient's occupational history revealed a chronic exposure to multiple petroleum

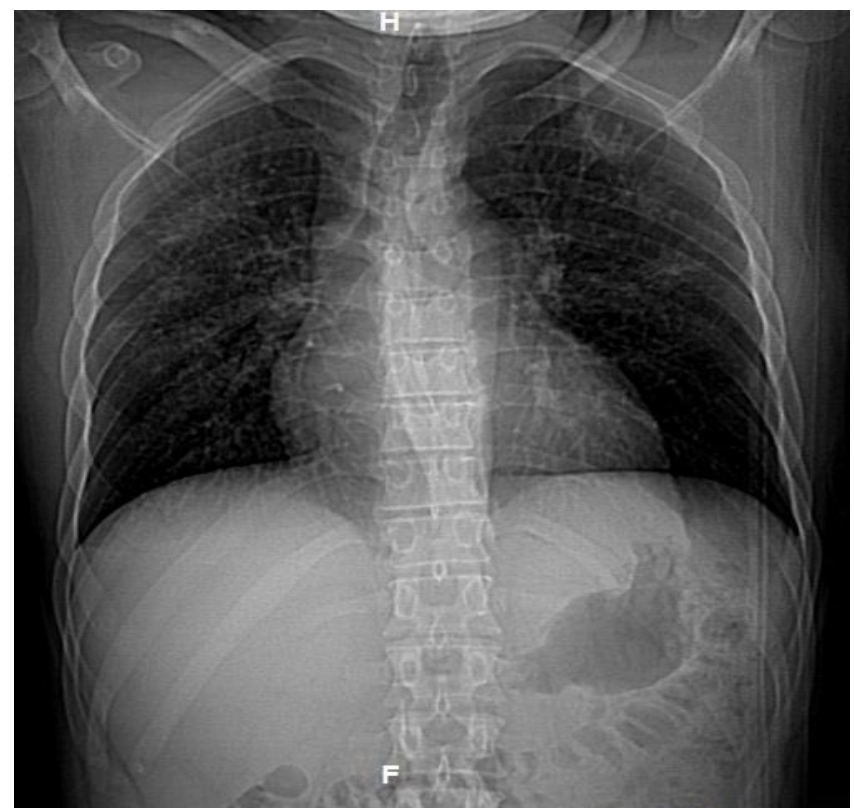

Figure 1: Chest radiograph demonstrating diffuse reticulonodular pattern throughout both lungs products without respiratory protective equipment. ELP was suspected and a second BAL was performed. A reevaluation of $\mathrm{BAL}$ results with specific staining and coloration demonstrated the presence of lipid-laden macrophages, confirming the diagnosis of lipoid pneumonia (Figure 4). Avoidance of the offending agent was prescribed and subsequent monitoring confirmed clinical and radiological improvement.

\section{DISCUSSION}

ELP is a rare condition. The diagnosis is difficult, since it does not have characteristic clinical or radiological features. ELP is caused by the inhalation or aspiration of fatty substances. These substances accumulate in the lungs because they are engulfed by alveolar macrophages without being metabolized.

Lipoid pneumonia is more frequent in children and the elderly, often due to an excessive use of mineral oil for the treatment of constipation. In such instances, the presentation may be in the acute form (2). This disease can also be caused by exposure to oily substances in the work area. Chronic exposure to low doses of oil, such as in diesel fuel siphoning, may cause a chronic presentation of lipoid pneumonia (2). A massive exposure to oil, such as in a fire-eater, may lead to an acute presentation of this disease (3). In the present case report, the patient had repeated inhalation of small quantities of an oily substance, while in previous studies, the occupational exposure was repeated aspiration of the substance (2-4). The offending agent described in this case is the multipurpose grease widely used in automotive and industrial applications. It is commonly used for lubrication, combining the properties of 2 or more specialized greases (5).

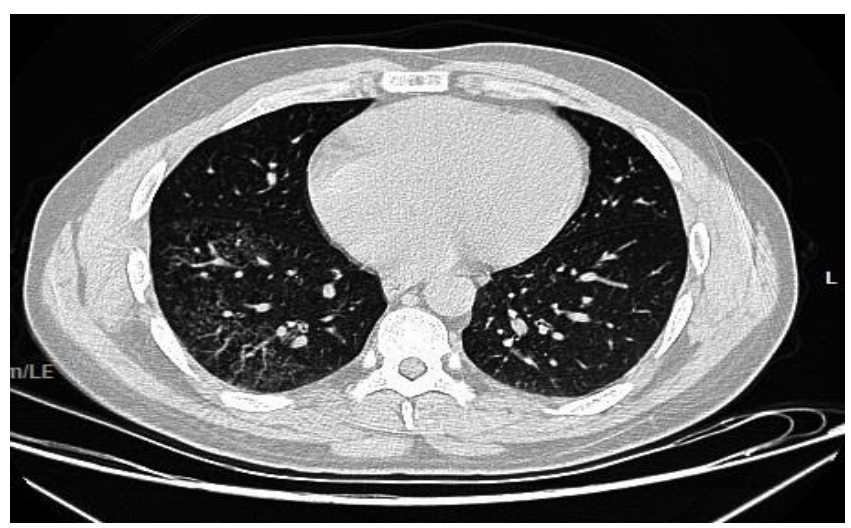

Figure 2: Computed tomography scan demonstrating diffuse micronodules in both lungs 


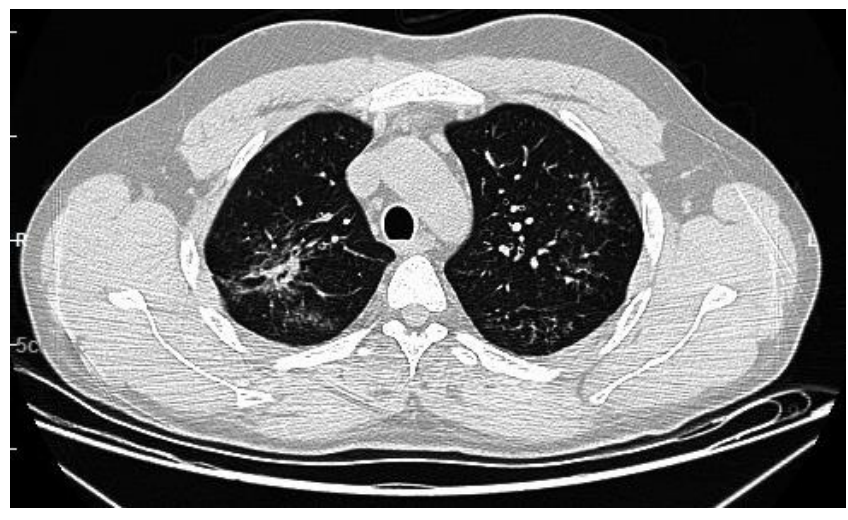

Figure 3: Computed tomography scan demonstrating bilateral airspace consolidations

Clinically, patients with chronic ELP are often asymptomatic. Symptomatic patients typically complain of a cough and dyspnea (6). Chronic ELP is less likely to cause fever or weight loss (7), as in the case described here. The diagnosis of ELP is usually delayed because it mimics other common diseases, such as tuberculosis (6). Our patient was suspected of having tuberculosis, but a sputum smear microscopy and culture were negative. Therefore, the diagnosis of lipoid pneumonia should be considered in the differential diagnosis of chronic pneumonia. The radiological manifestations of ELP are nonspecific. Chest radiographs frequently shows areas of groundglass opacity and consolidation. A mass-like lesion may be observed (8). Abnormalities are usually located in the lower or middle lobes in siphoners, due to the squatting posture assumed during the practice (4). In the case reported here, there was no predominant location of pulmonary lesions because he didn't use a single, consistent posture while working.

The diagnosis of lipoid pneumonia is confirmed by detecting lipid-laden macrophages in BAL fluid. In some cases, histological confirmation may be necessary (9). Some authors recommend that invasive procedures may be avoided when computed tomography shows specific signs of lipid infiltration of pulmonary parenchyma (10). Treatment of ELP has not yet been clearly established. The main treatment is the avoidance of exposure to the causal agent. Our patient demonstrated improvement following avoidance of multipurpose grease. Systemic corticosteroids have been shown to be effective in some cases $(2,4)$. Total pulmonary lavage has also been reported to be useful in the cortico-resistant form (6).

ELP due to occupational exposure to oil can be prevented by discontinuing some risky practices and the correct use of suitable respiratory protective equipment. Special medical surveillance is required for workers in order to

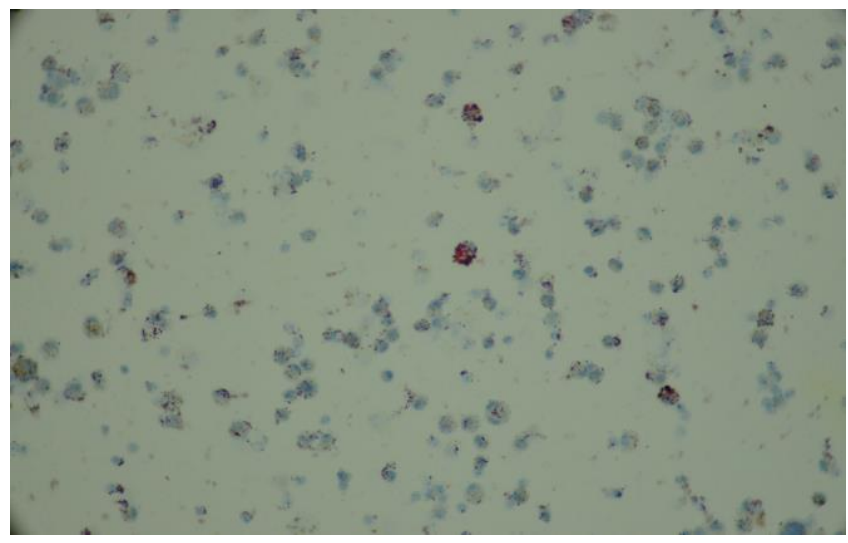

Figure 4: The presence of lipid-laden macrophages on bronchoalveolar lavage analysis (red-stained macrophages with Oil red O stain, 100x)

diagnose asymptomatic patients who should avoid further exposure to offending agents. Finally, there should be an emphasis on the importance of occupational exposure history in patients with non-resolving pneumonia when lipoid pneumonia is suspected. The occupational history should include information about routine tasks performed during a typical work shift and the use of chemicals such as paraffin (11), diesel (4), petroleum jelly, and cutting mist (1). In some cases, patients have limited knowledge of the substances to which they have been exposed. In such cases, physicians can ask for material safety data sheets which identify the composition of materials used in the workplace. Sometimes, referral to an occupational medicine specialist is appropriate.

\section{CONCLUSION}

ELP is a rare condition in healthy adults that can be a result of occupational exposure to fatty substances. The diagnosis is usually delayed because physicians often neglect occupational history. The identification and subsequent avoidance of the causal agent is the most important treatment. Physicians should be aware of the importance of investigating occupational exposure, especially for patients with non-resolving pneumonia.

\section{CONFLICTS OF INTEREST}

None declared.

\section{AUTHOR CONTRIBUTIONS}

Concept - F.D., M.H., K.J.H., M.L.M.; Planning and Design - F.D., M.H., K.J.H., M.L.M.; Supervision - F.D., M.H., K.J.H., M.L.M.; Funding -; Materials - M.H.; Data Collection and/or Processing - M.L.M.; Analysis and/or Interpretation - K.J.H.; Literature Review - F.D.; Writing F.D., M.H.; Critical Review - M.H., K.J.H. 


\section{YAZAR KATKILARI}

Fikir - F.D., M.H., K.J.H., M.L.M.; Tasarım ve Dizayn F.D., M.H., K.J.H., M.L.M.; Denetleme - F.D., M.H., K.J.H., M.L.M.; Kaynaklar -; Malzemeler - M.H.; Veri Toplama ve/veya İşleme - M.L.M.; Analiz ve/veya Yorum - K.J.H.; Literatür Taraması - F.D.; Yazıyı Yazan - F.D., M.H.; Eleştirel İnceleme - M.H., K.J.H.

\section{REFERENCES}

1. Gondouin A, Manzoni P, Ranfaing E, Brun J, Cadranel J, Sadoun D, et al. Exogenous lipid pneumonia: a retrospective multicentre study of 44 cases in France. Eur Respir J 1996; 9:1463-9. [CrossRef]

2. Yampara Guarachi GI, Barbosa Moreira V, Santos Ferreira A, Sias SM, Rodrigues CC, Teixeira GH. Lipoid pneumonia in a gas station attendant. Case Rep Pulmonol 2014; 2014:358761. [CrossRef]

3. Pielaszkiewicz-Wydra M, Homola-Piekarska B, Szcześniak E, Ciołek-Zdun M, Fall A. Exogenous lipoid pneumonia a case report of a fire-eater. Pol J Radiol 2012; 77:60-4. [CrossRef]

4. Venkatnarayan K, Madan K, Walia R, Kumar J, Jain D, Guleria R. "Diesel siphoner's lung": Exogenous lipoid pneumonia following hydrocarbon aspiration. Lung India 2014;31(1):63-6.[CrossRef]
5. Bloch HP. Practical Lubrication for Industrial Facilities. Lilburn, GA: Fairmont Press; 2000. [CrossRef]

6. Sias SM, Daltro PA, Marchiori E, Ferreira AS, Caetano RL, Silva CS, et al. Clinic and radiological improvement of lipoid pneumonia with multiple bronchoalveolar lavages. Pediatr Pulmonol 2009; 44:309-15. [CrossRef]

7. Baron SE, Haramati LB, Rivera VT. Radiological and clinical findings in acute and chronic exogenous lipoid pneumonia. J Thorac Imaging 2003; 18:217-24. [CrossRef]

8. Chiang IC, Lin YT, Liu GC, Chiu CC, Tsai MS, Kao EL. Exogenous lipoid pneumonia: serial chest plain roentgenography and high-resolution computerized tomography findings. Kaohsiung J Med Sci 2003; 19:593-8. [CrossRef]

9. Hadda V, Khilnani GC. Lipoid pneumonia: an overview. Expert Rev Respir Med 2010; 4:799-807. [CrossRef]

10. Weinstein M. First do no harm: The dangers of mineral oil. Paediatr Child Health 2001; 6:129-31. [CrossRef]

11. Han C, Liu L, Du S, Mei J, Huang L, Chen M, et al. Investigation of rare chronic lipoid pneumonia associated with occupational exposure to paraffin aerosol. J Occup Health 2016; 58:482-8. [CrossRef] 